\title{
Optimizing Absorbent Bentonite and Evaluation of Contaminants Removal from Petrochemical Industries Wastewater
}

\author{
Hooman Bahmanpour ${ }^{1}$, Sara Awhadi ${ }^{2}$, Javad Enjili ${ }^{3}$, Seyed Mohammad Hosseini ${ }^{4}$, \\ Hamid Raeisi Vanani ${ }^{5}$, Saeid Eslamian ${ }^{6}$, Kaveh Ostad-Ali-Askari ${ }^{{ }^{*} \text {, }}$ \\ ${ }^{1,2}$ Department of Environmental Engineering, Islamic Azad University, Shahroud Branch, Iran \\ ${ }^{3,4}$ MSc, Department of Chemical Engineering, Islamic Azad University, Shahroud Branch, Iran \\ ${ }^{5} \mathrm{MSc}$, Department of Water Engineering, Isfahan University of Technology, Isfahan, Iran \\ ${ }^{6}$ Full Professor, Department of Water Engineering, Isfahan University of Technology, Isfahan, Iran \\ $7^{7 *}$ Department of Civil Engineering, Isfahan (Khorasgan) Branch, Islamic Azad University, Isfahan, Iran
}

\section{*Corresponding Author:}

Kaveh Ostad-Ali-Askari, Department of Civil Engineering, Isfahan (Khorasgan) Branch, Islamic Azad University, Isfahan, Iran. Email: Koa.askari@khuisf.ac.ir

\begin{abstract}
The aim of this research was to show the better use of internal resources and increased capability of utilizing and optimizing minerals. Also, in this research we tried to present a new way of petrochemical wastewater treatment. In this sample of bentonite, after the production process in microwave through digestion method with Nano Precision, a long chain of detergents was processed and optimized with an organic material (dimethyl octadecyl ammonium chloride). In the beginning of tests, a statistical method was drawn by MINITAB software and Taguchi method. Sampling was made in different times and testing started by a standard method. Among measuring factors, 5 factors of turbidity, TSS, TDS, pH, and COD were evaluated and their changes were investigated in different times based on the amount and type of materials. The effluent COD and BOD are very important. The petrochemical wastewater was measured and it was90ppm(COD) and 3 ppm(BOD). Also, the highestlevel of turbidity for material A (modified bentonite) was 1.2 NTU with 10mg/L of sludge. Considering that the country needed a better wastewater treatment through environment protection, modification of bentonite's structure, and nano application process in this industry along with various available methods, we aimed to take a step towards the development of the country.
\end{abstract}

Keywords: Bentonite, wastewater treatment, design of Taguchi method tests, turbidity, COD, TDS, TSS

\section{INTRODUCTION}

Inattention towards wastewater treatment operations can lead to contamination of water and soil resources and, consequently, infectious and chronic diseases. Physical, chemical, and biological wastewater treatment methods are of special importance. Moreover, given the limitation of water sources, when wastewater is treated appropriately and is compatible with environmental standards, the treated wastewater can be reused in different fields such as agriculture (1). Protection of valuable sources, like bentonite soil, and their use in the treatment of industrial wastewater are from effective solutions for improving the level of environmental cleanliness (2).

The purpose of this research was, first of all, the optimization of bentonite soil and then the use of this material to remove different pollutants from industrial (petrochemical) wastewater. Petrochemical wastewater is very dangerous and contains various pollutants.

Bentonite is a mineral from the category of clays or pseudo-clays generated from inflated minerals. In general, it contains montmorillonite and a little beidellite. For the same reason, bentonite is a clay species which contains $85 \%-90 \%$ of montmorillonite mineral. The term "bentonite" was introduced for the first time in 1898 by Knight as clay, and then extracted from Benton Shale. This termis said to have come from the name of a region called Montmorillon in the south of France, containing large 
sources of bentonite $(3,4)$. On the other side, bentonite is also referred to as clay mainly composed of smectite minerals (regardless of its origin) with the following chemical formula(5):

$(\mathrm{Na}, \mathrm{Ca})_{0.33}(\mathrm{Al}, \mathrm{Mg})_{2} \mathrm{Si}_{4} \mathrm{O}_{10}(\mathrm{OH})_{2} \cdot \mathrm{nH}_{2} \mathrm{O}$.

The different types of bentonite are each named after the respective dominant element, such as potassium $(\mathrm{K})$, sodium $(\mathrm{Na})$, calcium $(\mathrm{Ca})$, and aluminium $(\mathrm{Al})$. Experts debate a number of nomenclatorial problems with the classification of bentonite clays. Bentonite usually forms from weathering of volcanic ash, most often in the presence of water. However, the term bentonite, as well as similar clay called tonstein, has been used to describe clay beds of uncertain origin. For industrial purposes, two main classes of bentonite exist: sodium and calcium bentonite (3-5). Bleaching property and the quantity of water absorbed by bentonite depend on the type of mineral(s) of smectite group. The swellrate and bleaching properties of bentonites is normally not desirable; as a result, it is necessary to make some modifications so that its properties increase. Bentonite is made of alumina and silica flakes with weak bonds which can be separated in aqueous media to 0.003 micrometers thick and 0.1 micrometer length. Easy separation property and negative electric charge cause their wide spread in water. Bentonite contains interchangeable cations $\mathrm{Ca}^{2+}, \mathrm{Na}^{2+}$ or $\mathrm{Mg}^{2+}$ and has a higher ion exchange capacity than other minerals except zeolite. This property impacts its commercial characteristics and its classification takes place on the same basis, such as sodium bentonite with a very high ability to swell and calcium bentonite with a poor ability to swell. Another major difference between these two types of minerals is that the type containing sodium is stable at a temperature of $400^{\circ} \mathrm{C}$. On the other hand, calcium bentonite reactions with sodium carbonate so that its swelling property is increased $(6,7)$.

Due to properties such as softening and swelling, a relatively good ability to be mixed with water, plasticity, adhesiveness, absorbency and ..., bentonite is widely used in various areas like the production of drilling mud, casting sand preparation, preventing water leak in dams and irrigation channels, preparation of transparent liquids such as fruit juices, acting as water clarifier and smoother of liquids like paraffin, pelletizing of minerals including iron ore, pelletizing of animal feed, acting as carrier agent in paints and other spray products, preparation of animal and plant toxins, filler in industries like papermaking, production of cleaners and detergents, production of ceramics, bleaching, and treatment of oils (8).

The main research question was whether modified bentonite can be reducing parameters of COD, TDS, and TSS effluent to be effective?

For this purpose, 1 sample of raw bentonite, 2 types of modified bentonite and 2 types of activated bentonite and also 1 type of nano-bentonite was used. The limitation of study was included: Lack of financial resources and low reproducibility (3 times).

Although this is a relatively new topic, but several studies have been conducted on the benefits and uses of bentonite in wastewater treatment. Studies related to the research subject-matter included:

- Natural zeolites is effective in water treatment by Margeta et al., (2013);

- Evaluation of natural zeolites in the purification and separation of gases by Ackley et al., (2003);

- Investigation of the possibility of removing copper, nickel and lead from aqueous solutions using bentonite by Futalan et al., (2012);

- Using bentonite in chemical treatment of industrial wastewater by Sahu and Chaudhari (2013);

- Removal of emerging contaminants from water and wastewater by adsorption process with materials such as bentonite by Grassi et al., (2012);

- Evaluation of the application of bentonite to remove heavy metals from wastewater by Al-Jlil (2010);

- Evaluation of bentonite soil modification using sulfate and anionic phosphate for the removal of heavy metals by Olu-Owolabi and Unuabonah (2010);

- Feasibility of using sodium bentonite in removing heavy metals by Triantafyllou et al., (1999);

- Evaluation of the treatment of wastewater contaminated with cobalt using Saudi activated bentonite by Al-Shahriani (2013). (9 - 17). 


\section{Materials AND Methods}

This was an applied research as for outputs and a cross-sectional one in terms of application time. Basic information was gathered firstly through investigating theoretical fundamentals in previous literature. Then we began to identify issues related to wastewater in petrochemical industries by holding brainstorming sessions with the participation of engineers of refineries and petrochemical sites. To do tests, the wastewater of Khorasan Petrochemicals Company and the bentonite available in Kerman were used.

For a more precise identification of forming minerals, the bentonite sample in the laboratory of Golgohar-e Sirjan Company was analyzed through X-ray diffraction (XRD) method. Due to their structural formulation, these materials absorb OAT and reduce its quantity; therefore, this quantity can be diminished by modifying and/or optimizing the bentonite.

Next, five types of bentonites (raw bentonite D; modified bentonite A and B; calcium bentonite E, sodium bentonite $\mathrm{F}$ and German nano bentonite $\mathrm{C}$ ) were supplied and tested.

\subsection{Bentonite Optimization Method}

The purpose of optimization was raising the level of active contact surface and better efficiency catalytic properties cations sodium, calcium and potassium exchange.Organoclay method was used in order to optimize the tested bentonite (18). Organoclay is an organically modified phyllosilicate, derived from a naturally occurring clay mineral(19)(20). By exchanging the original interlayer cations for organocations (typically quaternary alkyl ammonium ions) an organophilic surface is generated, consisting of covalently linked organic moieties. The lamellar structure remains analogous to the parent phyllosilicate. Organoclay manufacturing process was carried out without the application of heat and acid activation. For this purpose, $2 \mathrm{~g}$ of the raw bentonite sample was prepared which was gradually added to $500 \mathrm{cc}$ water; then it was stirred by a mechanical shaker for 1 hour at a speed of $160 \mathrm{rpm} .2 .4 \mathrm{~g}$ of dimethyl octadecyl ammonium chloride was added. This time the blending speed was increased to $120 \mathrm{rpm}$, and then it was continued to blend for 2 hours. All these steps were conducted at room temperature, and drying was done after 2 hours. It should be noted that the bentonite powder shall not be filteredandbe dried with the same water inside it (21)(22). A vacuum oven at a temperature of $30^{\circ} \mathrm{C}$ can be used to accelerate the drying process.

Table 1 and Table 2 illustrate the analysis of raw and modified bentonite samples.

Table1. Analysis of raw bentonite Dsample

\begin{tabular}{|c|c|c|c|c|c|c|c|}
\hline $\mathrm{TiO}_{2}$ & $\mathrm{MgO}$ & $\mathrm{CaO}$ & $\mathrm{K}_{2} \mathrm{O}$ & $\mathrm{Na}_{2} \mathrm{O}$ & $\mathrm{Fe}_{2} \mathrm{O}_{3}$ & $\mathrm{Al}_{2} \mathrm{O}_{3}$ & $\mathrm{SiO}_{2}$ \\
\hline $0.8 \%$ & $5.22 \%$ & $1.04 \%$ & $0.35 \%$ & $3.09 \%$ & $5.96 \%$ & $14.77 \%$ & $60.34 \%$ \\
\hline
\end{tabular}

Table2. Analysis of bentonite samples tested

\begin{tabular}{|c|c|c|c|c|c|c|c|c|c|}
\hline Compound name & Loi & $\mathrm{TiO}_{2}$ & $\mathrm{MgO}$ & $\mathrm{CaO}$ & $\mathrm{K}_{2} \mathrm{O}$ & $\mathrm{Na}_{2} \mathrm{O}$ & $\mathrm{Fe}_{2} \mathrm{O}_{3}$ & $\mathrm{Al}_{2} \mathrm{O}_{3}$ & $\mathrm{SiO}_{2}$ \\
\hline Modified bentonite A and B & $7.70 \%$ & 0 & $5.22 \%$ & $1.04 \%$ & $35 \%$ & $3.09 \%$ & $5.96 \%$ & $14.77 \%$ & $60.38 \%$ \\
\hline Calcium bentonite B & $7.87 \%$ & 0 & $4.81 \%$ & $25 \%$ & $29 \%$ & $4.64 \%$ & $6.27 \%$ & $12.74 \%$ & $60.68 \%$ \\
\hline Sodium bentonite F & 0 & 269 & 1.86 & 1.68 & 2.831 & 9.3 & 1.67 & 7.631 & 68.72 \\
\hline German Nano-bentonite C & $15.45 \%$ & $62 \%$ & $3.29 \%$ & $1.97 \%$ & $86 \%$ & $98 \%$ & $5.62 \%$ & $19.60 \%$ & $50.95 \%$ \\
\hline
\end{tabular}

Table3. Analysis of the wastewater entering the treatment plant

\begin{tabular}{|c|c|c|c|c|c|c|}
\hline $\mathbf{p H}$ & TEMP $\left({ }^{\circ} \mathbf{c}\right)$ & $\begin{array}{c}\text { Change in } \\
\mathbf{p H}\end{array}$ & $\begin{array}{c}\text { Turbidity } \\
\text { (NTU) }\end{array}$ & EC (ms) & TDS (ppm) & COD (ppm) \\
\hline 7.05 & 22.5 & 3 & 16 & 1.96 & 2300 & 3400 \\
\hline
\end{tabular}

Taguchi method was used in the design of experiments. The main effective factors included materials and the rate of changes in $\mathrm{pH}$ studied at 5 levels.

\section{Conclusion AND Discussion}

During the sampling in several stages and at different times and, then, the measuring of all desired parameters, the quality of the wastewater entering the treatment plant of the petrochemical company was determined as follows: 
Hooman Bahmanpour et al.

According to Taguchi method, the wastewater sample tested was measured with each of the given bentonites. The results are as shown in Table 4.

Table4. Results of wastewater analysis after its contact with selected bentonites

\begin{tabular}{ccccccc}
\hline Sample & $\mathbf{p H}$ & $\begin{array}{c}\text { Change } \\
\text { in } \mathbf{p H}\end{array}$ & $\begin{array}{c}\text { Turbidity } \\
\text { (NTU) }\end{array}$ & EC (ms) & $\begin{array}{c}\text { TDS } \\
\text { (ppm) }\end{array}$ & $\begin{array}{c}\text { Settled } \\
\text { sludge (g/lit) }\end{array}$ \\
\hline A & 2.50 & 2.42 & 1.26 & 3.95 & 2.96 & 10 \\
A & 5.00 & 4.30 & 2.30 & 2.84 & 3.12 & 25 \\
A & 7.50 & 7.00 & 4.00 & 2.50 & 3.00 & 25 \\
A & 10.00 & 8.6 & 4.5 & 3.00 & 1.10 & 15 \\
A & 12.50 & 10.00 & 20.00 & 2.88 & 15.00 & 15 \\
B & 2.50 & 3.00 & 20.50 & 4.00 & 2.96 & 60 \\
B & 5.00 & 5.80 & 27.40 & 2.85 & 2.13 & 50 \\
B & 7.50 & 7.40 & 40.00 & 3.00 & 2.00 & 50 \\
B & 10.00 & 9.60 & 76.00 & 2.00 & 1.98 & 30 \\
B & 12.50 & 12.00 & 86.00 & 1.90 & 3.20 & 50 \\
C & 2.50 & 2.60 & 36.00 & 3.95 & 2.96 & 90 \\
C & 5.00 & 5.60 & 40.05 & 2.84 & 2.13 & 120 \\
C & 7.50 & 7.00 & 40.02 & 1.46 & 1.10 & 200 \\
C & 10.00 & 10.50 & 50.00 & 1.22 & 0.95 & 180 \\
C & 12.50 & 12.00 & 76.90 & 1.23 & 0.92 & 160 \\
D & 2.50 & 2.42 & 8.50 & 1.00 & 2.96 & 10 \\
D & 5.00 & 4.50 & 12.00 & 0.90 & 2.13 & 15 \\
D & 7.50 & 7.00 & 19.00 & 0.98 & 1.10 & 15 \\
D & 10.00 & 9.00 & 31.00 & 0.95 & 0.95 & 10 \\
D & 12.50 & 11.00 & 79.00 & 0.90 & 0.92 & 20 \\
E & 2.50 & 3.3 & 5.00 & 1.32 & 0.95 & 20 \\
E & 5.00 & 6.00 & 6.20 & 1.38 & 0.92 & 25 \\
E & 7.50 & 7.50 & 7.00 & 1.23 & 0.96 & 25 \\
E & 10.00 & 9.00 & 8.00 & 1.80 & 0.95 & 30 \\
E & 12.50 & 10.60 & 9.30 & 2.00 & 0.92 & 25 \\
F & 2.50 & 2.90 & 10.90 & 1.50 & 0.80 & 15 \\
F & 5.00 & 4.00 & 13.09 & 1.43 & 0.94 & 20 \\
F & 7.50 & 6.30 & 21.30 & 1.56 & 0.98 & 25 \\
F & 10.00 & 8.40 & 32.90 & 1.65 & 0.95 & 20 \\
F & 12.50 & 10.50 & 40.60 & 1.43 & 0.95 & 25 \\
\hline & & & & & & \\
\hline
\end{tabular}

According to the results obtained from 6 samples of bentonite, the sample A had the highest turbidity level compared with other samples of bentonite. Similarly, COD was measured and it was 90ppm and also, BOD was measured and it was $3 \mathrm{ppm}$. These results indicate that the modified bentonite had affected the wastewater sample (Table 5).

Table5. Results of using selected bentonite (type A) on the wastewater sample from petrochemical industries

\begin{tabular}{|c|c|c|}
\hline Parameter & Pre-treatment & Post-treatment \\
\hline BOD & 1000 & 3 \\
\hline COD & 5000 & 90 \\
\hline TDS & 5000 & 40 \\
\hline TSS & 1000 & 180 \\
\hline TIFF & 18000 & 6 \\
\hline EC & 640 & 2 \\
\hline Hardness & 700 & 300 \\
\hline Sulfate & 5000 & 1880 \\
\hline Chloride & 300 & 120 \\
\hline Inlet flow & - & $300-2000$ \\
\hline
\end{tabular}

Figure 1 shows the main effects of the sample for $\mathrm{S} / \mathrm{N}$ ratios. 
Optimizing Absorbent Bentonite and Evaluation of Contaminants Removal from Petrochemical Industries Wastewater

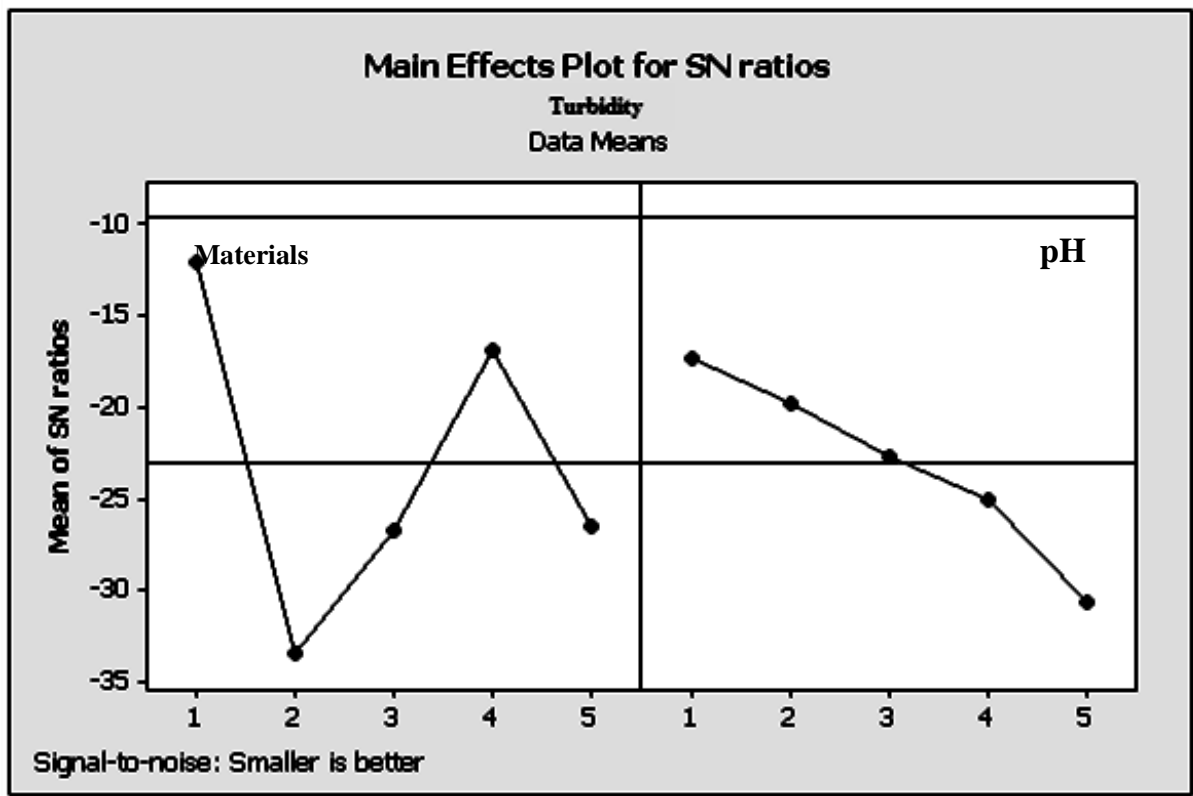

Fig1. Results of the main data related to petrochemical wastewater

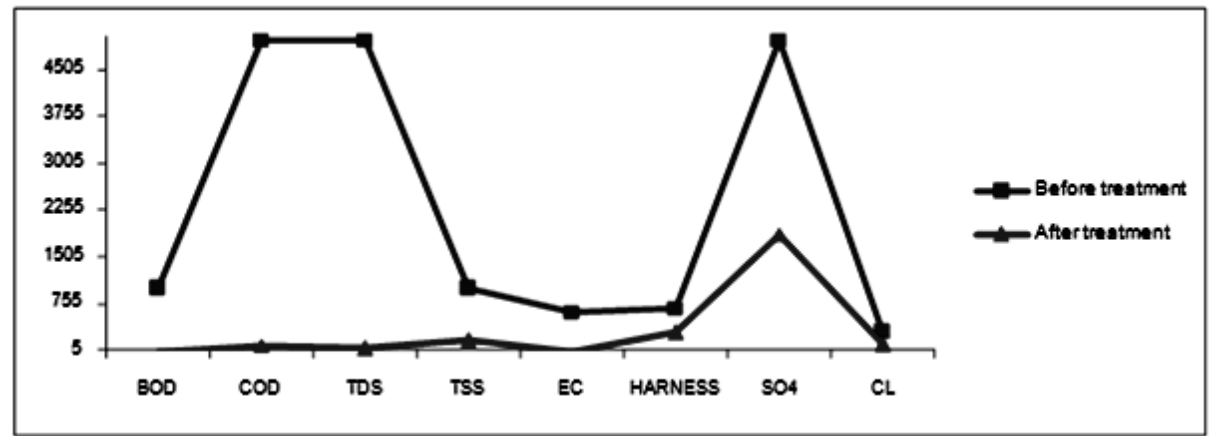

Fig2. Comparison of parameters tested with bentonite $(A)$ pre-and post-treatment

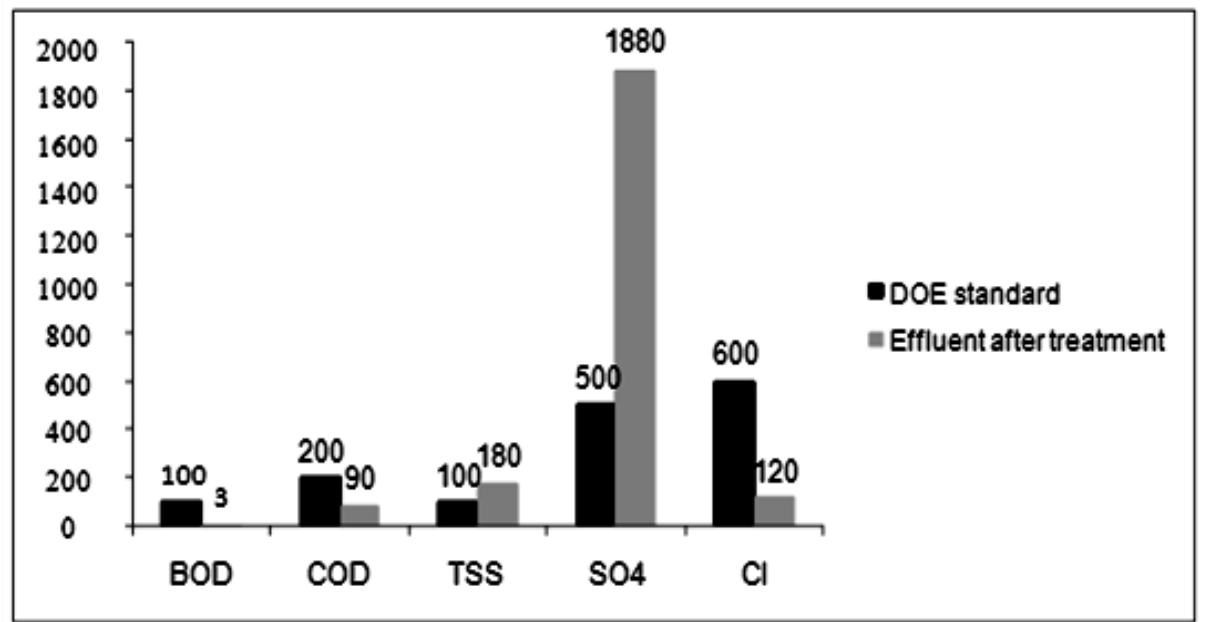

Fig3. Comparison of the results of wastewater treatment with bentonite (A) and national standards to use wastewater for irrigation of landscape (DOE, 2012)

The diagram shown above illustrates the effect of materials and $\mathrm{pH}$ on turbidity. It should be noted that absolute numbers ( $\mathrm{SN})$ are taken into consideration in this diagram so that the smallest data indicates the best result. The effect of material on turbidity is investigated at the left side, while the effect of $\mathrm{pH}$ on turbidity is examined at the right side (23)(24)(25). Firstly, material number 1, bentonite $\mathrm{A}$, has the highest effect on turbidity, and the material number 2, German nano bentonite, has the lowest effect. In this section, the impact of materials is considered regardless of the $\mathrm{pH}$ effect. On the left, $\mathrm{pH}$ diagram indicates that the more acidic is the solution, the higher its effect will be (i.e. 


\section{Hooman Bahmanpour et al.}

type 1 with an acidity of 2.5), and the more alkaline it is (i.e. type 2 with an alkaline $\mathrm{pH}$ of 12.5), the lower its effect will be. The effect of $\mathrm{pH}$ on turbidity is linear. The more the acidity, the greater the turbidity and the alkalinity level in wastewater indicates that its conditions are far from ideal. However, this is not true for the effect of materials (26)(27).

This diagram shows that the materials have no interaction (i.e. decrease and/or increase of one factor has no effect on the other). Materials, $\mathrm{pH}$, and their influence line are the same.

It should be noted that the smallest values in diagrams above represent the best values and the absolute valuesshall be taken into consideration. The effect of the change in the materials and the $\mathrm{pH}$ is the same (equal). Any line on the $\mathrm{pH}$ diagram indicates a $\mathrm{pH}$ value and on the materials diagram indicates a material. According to Table 6 , which shows the effect of bentonite materials and $\mathrm{pH}$, the turbidity obtained is desirable for all samples. Also, the volume of the settled sludge has decreased. The optimal condition was for material a (modified bentonite) and with a turbidity of 1.2 and a sludge volume of $10 \mathrm{mg} / \mathrm{L}$. The turbidity level is completely consistent with national and international standards $(28)(29)(30)$.

Table6. Final data on the petrochemical wastewater

\begin{tabular}{|c|c|c|c|c|c|c|c|c|}
\hline Materials & $\mathrm{pH}$ & Change in $\mathrm{pH}$ & $\begin{array}{c}\text { Turbidity } \\
(\mathrm{NTU})\end{array}$ & EC $(\mathrm{ms})$ & TDS $(\mathrm{ppm})$ & $\begin{array}{c}\text { Settled sludge } \\
(\mathrm{g} / \mathrm{lit})\end{array}$ & SNRA1 & MEAN1 \\
\hline $\mathrm{A}$ & 2.5 & 2.42 & 1.26 & 3.95 & 2.96 & 10 & -2.00741 & 1.26 \\
\hline $\mathrm{A}$ & 5 & 4.3 & 2.3 & 2.84 & 3.12 & 25 & -7.23456 & 2.3 \\
\hline $\mathrm{A}$ & 7.5 & 7 & 4 & 2.5 & 3 & 25 & -12.0412 & 4 \\
\hline $\mathrm{A}$ & 10 & 8.6 & 4.5 & 3 & 1.098 & 15 & -13.0643 & 4.5 \\
\hline $\mathrm{A}$ & 12.5 & 10 & 20 & 2.88 & 0.9 & 15 & -26.0206 & 20 \\
\hline $\mathrm{C}$ & 2.5 & 2.6 & 36 & 3.95 & 2.96 & 90 & -31.1261 & 36 \\
\hline $\mathrm{C}$ & 5 & 5.6 & 40.05 & 2.84 & 2.13 & 120 & -32.0521 & 40.05 \\
\hline $\mathrm{C}$ & 7.5 & 7 & 40.02 & 1.46 & 1.095 & 200 & -32.0455 & 40.02 \\
\hline $\mathrm{C}$ & 10 & 10.5 & 50 & 1.22 & 0.95 & 180 & -33.9794 & 50 \\
\hline $\mathrm{C}$ & 12.5 & 12 & 76.9 & 1.23 & 0.92 & 160 & -37.7185 & 76.9 \\
\hline $\mathrm{D}$ & 2.5 & 2.42 & 8.5 & 0.9 & 2.96 & 10 & -18.5884 & 8.5 \\
\hline $\mathrm{D}$ & 5 & 4.5 & 12 & 0.9 & 2.13 & 15 & -21.5836 & 12 \\
\hline $\mathrm{D}$ & 7.5 & 7 & 19 & 0.98 & 1.095 & 15 & -25.5751 & 19 \\
\hline $\mathrm{D}$ & 10 & 9 & 31 & 0.95 & 0.95 & 10 & -29.8272 & 31 \\
\hline $\mathrm{D}$ & 12.5 & 11 & 79 & 0.9 & 0.92 & 20 & -37.9525 & 79 \\
\hline $\mathrm{E}$ & 2.5 & 3.3 & 5 & 1.32 & 0.95 & 10 & -13.9794 & 5 \\
\hline $\mathrm{E}$ & 5 & 6 & 6.2 & 1.38 & 0.92 & 15 & -15.8478 & 6.2 \\
\hline $\mathrm{E}$ & 7.5 & 7.5 & 7 & 1.23 & 0.96 & 15 & -16.902 & 7 \\
\hline $\mathrm{E}$ & 10 & 9 & 8 & 1.8 & 0.95 & 10 & -18.0618 & 8 \\
\hline $\mathrm{E}$ & 12.5 & 10.6 & 9.3 & 2 & 0.92 & 20 & -19.3697 & 9.3 \\
\hline F & 2.5 & 2.9 & 10.9 & 1.5 & 0.8 & 15 & -20.7485 & 10.9 \\
\hline F & 5 & 4 & 13.09 & 1.43 & 0.94 & 20 & -22.3388 & 13.09 \\
\hline F & 7.5 & 6.3 & 21.3 & 1.56 & 0.98 & 25 & -26.5676 & 21.3 \\
\hline F & 10 & 8.4 & 32.9 & 1.65 & 0.95 & 20 & -30.3439 & 32.9 \\
\hline F & 12.5 & 10.5 & 40.6 & 1.43 & 0.95 & 25 & -32.1705 & 40.6 \\
\hline
\end{tabular}

Table 7depicts the effect of each of the bentonite's material and the pH. For example, material $\mathrm{A}$ has an $88 \%$ impact on the wastewater.

Table7. Effect of materials and $p H$ on the petrochemical wastewater

\begin{tabular}{|c|c|c|c|}
\hline Materials & Materials effect & pH effect & pH \\
\hline A & $88 \%$ & $12 \%$ & 2.5 \\
\hline C & $64 \%$ & $36 \%$ & 5 \\
\hline D & $73 \%$ & $27 \%$ & 7.5 \\
\hline E & $80 \%$ & $20 \%$ & 10 \\
\hline F & $70 \%$ & $30 \%$ & 12.5 \\
\hline TOTAL & 21.31 & 13.35 & \\
\hline
\end{tabular}

The obtained results show that all tested parameters are significantly reduced and improved by the Type abentonite post-treatment. Compared with the existing standards on the use of treated 
wastewater to be used for irrigation of landscape and agriculture, however, sulfate and TSS are still higher than approved despite their decrease post-treatment (than their initial condition), and the use of complementary methods is therefore required(31)(32).

Results indicate that sample 1 (bentonite A) has been the best efficiency. Optimum condition was in $\mathrm{pH}=2.5$ (Acidic). Thus, modified bentonite (sample A), have been better results than German bentonite (sample C). In addition to lower cost of this bentonite is an advantage.

The innovative aspect of this research included using of new modification method for bentonite and also simultaneous use of several types of bentonite to petrochemical wastewater treatment and compares the results.

\section{REFERENCES}

[1] Bartone, C and M. Mara. 2010. Improving wastewater use in agriculture: An emerging priority. Water Anchor (ETWWA). Energy transport and water department. 190: 1-10.

[2] Syafalni, R. Abdullah, I. Abustan, and A. N. Mohd Ibrahim. 2013. Wastewater treatment using bentonite, the combinations of bentonite-zeolite, bentonite-alum, and bentonite-limestone as adsorbent and coagulant. International Journal of Environmental Sciences. 4 (3): 379- 391.

[3] STM Standard C 242. 2001, Standard Terminology of Ceramic Whitewares and Related Products, ASTM International, West Conshohocken, PA.

[4] Stokes, Geoffrey. Handbook of Electrical Installation Practice. John Wiley \& Sons. 2008. ISBN 978-1-4051-4767-5.

[5] Tahir. S. S., Naseem. R. 2009. Removal of Cr from tannery wastewater by adsorption on Bentonite clay, p. 123.

[6] Sheta, A.S., Falatah, A.M., Al-Sewailem, M.S., Khaled, E.M., Sallam, A.S. 2003. Sorption characteristics of zinc and iron by natural Zeolite and Bentonite. Microporous and Mesoporous Materials 61, pp. 127-136.

[7] Chiesworth, W., Vanstraaten, P., Sadura, S. 1987. Solubility of apatite in clay and Zeolite bearing systems: applications to agriculture. Applied Clay Science, 2, pp. 291-297.

[8] Hosterman, J.W., and Patterson S.H. 1992. Bentonite and Fuller's earth resources of the United States. U.S. Geological Survey Professional Paper 1522. United States Government Printing Office, Washington D.C., USA.

[9] Margeta, K., Logar, N.Z., Šiljeg, M., and Farkaš, A. 2013. Natural zeolites in water treatmenthow effective are their use. Chapter 5. http://dx.doi.org/10.5772/50738.

[10] Ackleyet, M.W., Rege, S.U., and Saxena, H. 2003. Application of natural zeolites in the purification and separation of gases. Microporous and Mesoporous Materials. 61 (1-3): 25-42.

[11] Futalan, C.M., Tsai, W.C., Lin, S.S., Hsien, K.J., Dalida, M.L., and Wan, M.W. 2012. Copper, nickel and lead adsorption from aqueous solution using chitosan-immobilized on bentonite in a ternary system. Sustainable Environment Research. 22 (6): 345-355.

[12] Sahu, O.P., and Chaudhari, P.K.2013. Review on chemical treatment of industrial waste water. J. Appl. Sci. Environ. Manage. 17 (2): 241-257. DOI: http://dx.doi.org/10.4314/jasem.v17i2.8.

[13] Grassi, M., Kaykioglu, G., Belgiorno, V., and Lofrano, G.2012. Removal of emerging contaminants from water and wastewater by adsorption process. Chapter 2. DOI: $10.1007 / 978-$ 94-007-3916-1.

[14] Al-Jlil, S.A. 2010. Removal of heavy metals from industrial wastewater by adsorption using local bentonite clay and roasted date pits in Saudi Arabia. Trends in Applied Sciences Research. 5 (2): $138-145$.

[15] Olu-Owolabi, B.I., and Unuabonah, E.I. 2010. Kinetic and thermodynamics of the removal of $\mathrm{Zn}^{2+}$ and $\mathrm{Cu}^{2+}$ from aqueous solution by sulphate and phosphate-modified Bentonite clay. Journal of Hazardous Materials. 184(1-3): 731-738.

[16] Triantafyllou, S., Christodoulou, E., and Neou-Syngouna, P. 1999. Removal of Nickel and Cobalt from aqueous solutions by Na-activated bentonite. Clays and Clay Minerals. 47 (5): $567-$ 572.

[17] Al-shahriani, S. 2013. Treatment of the wastewater contaminated with cobalt using sudi active Bentonite, Alexandria engineering journal.Volume 53, Issue 1, March 2014, Pages 205-211.

[18] Bardziński, P.J. 2014. On the impact of intermolecular interactions between the quaternary ammonium ions on interlayer spacing of quat-intercalated montmorillonite: A molecular mechanics and ab-initio study. Applied Clay Science. 95: 323-339. 
[19] Shayannejad, M., Akbari, N., Ostad-Ali-Askari, K. 2015, Study of modifications of the river physical specifications on muskingum coefficients, through employment of genetic algorithm. International Journal of Development Research. 5(3): 3782-3785.

[20] Ostad-Ali-Askari, K., Shayannejad, M., Ghorbanizadee-Kharazi, H. 2015, Assessment of artificial neural network performance and exponential regression in prediction of effective rainfall, International Journal of Development Research. 5(3): 3791-3794.

[21] Ostad-Ali-Askari, K., Shayannejad, M. 2015, The Study of Mixture Design for Foam Bitumen and the Polymeric and Oil Materials Function in Loose Soils Consolidation. Journal of Civil Engineering Research. 5(2): 39-44. DOI: 10.5923/j.jce.20150502.04

[22] Sayedipour, M., Ostad-Ali-Askari, K., Shayannejad, M. 2015, Recovery of Run off of the Sewage Refinery, a Factor for Balancing the Isfahan-Borkhar Plain Water Table in Drought Crisis Situation in Isfahan Province-Iran. American Journal of Environmental Engineering. 5(2): 43-46. DOI: 10.5923/j.ajee.20150502.02

[23] Ostad-Ali-Askari, K., Shayannejad, M. 2015, Developing an Optimal Design Model of Furrow Irrigation Based on the Minimum Cost and Maximum Irrigation Efficiency. International Bulletin of Water Resources \& Development. 3(2): 18-23.

[24] Shayannejad M, Ostad-Ali-Askari K. Modeling of solute movement in groundwater. Kankash publisher. First edition. 2015. ISBN: 978-600-136-256-9.

[25] Ostad-Ali-Askari K. Nitrate pollution in groundwater. Horoufchin publisher. First Edition, 2015. ISBN: 978-600-7419-23-6.

[26] Soltani-Todeshki, A. R., Raeisi-Vanani, H., Shayannejad, M., Ostad-Ali-Askari, K. 2015, Effects of magnetized municipal effluent on some chemical properties of soil in furrow irrigation. International Journal of Agriculture and Crop Sciences. 8(3): 482-489.

[27] Raeisi-Vanani, H., Soltani Todeshki, A. R., Ostad-Ali- Askari, K., Shayannejad, M. 2015, The effect of heterogeneity due to inappropriate tillage on water advance and recession in furrow irrigation. Journal of Agricultural Science. 7(6):127-136.

[28] Ostad-Ali-Askari, K., Shayannejad, M. 2015, Usage of rockfill dams in the HEC-RAS software for the purpose of controlling floods. American Journal of Fluid Dynamics. 5(1): 23-29. DOI: 10.5923/j.ajfd.20150501.03.

[29] Ostad-Ali-Askari, K., Shayannejad, M. 2015, Presenting a Mathematical Model for Estimating the Deep Percolation Due to Irrigation. International Journal of Hydraulic Engineering. 4(1): 1721. DOI: 10.5923/j.ijhe.20150401.03.

[30] Ostad-Ali-Askari, K., Shayannejad, M. 2015, Developing an Optimal Design Model of Furrow Irrigation Based on the Minimum Cost and Maximum Irrigation Efficiency. International Bulletin of Water Resources and Development. 3(2): 18-23.

[31] Ostad-Ali-Askari, K., Shayannejad, M. 2015, Study of sensitivity of Autumnal wheat to under irrigation in Shahrekord, Shahrekord City, Iran. International Journal of Agriculture and Crop Sciences. 8 (4): 602-605.

[32] Ostad-Ali-Askari, K., Shayannejad, M. 2015, The Reviews of Einstein's Equation of Logarithmic Distribution Platform and the Process of Changes in the Speed Range of the Karkheh River, Khuzestan province, Iran. International Journal of Development Research. 5(3): 3786-3790.

\section{AUTHORS' BIOGRAPHY}

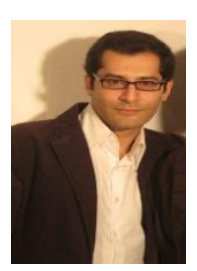

Hooman Bahmanpour, Department of Environmental Engineering, Islamic Azad University, Shahroud Branch, Shahroud, Iran.

Sara Awhadi, Department of Environmental Engineering, Islamic Azad University, Shahroud Branch, Damavand, Iran

Javad Enjili, MSc, Department of Chemical Engineering, Islamic Azad University, Shahroud Branch, Shahroud, Iran 

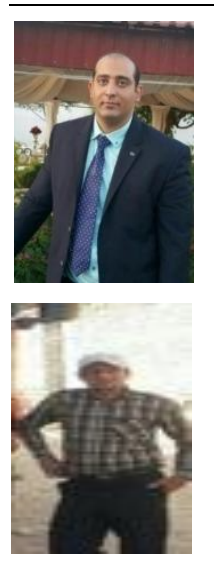

Hamid Raeisi Vanani, MSc, Department of Water Engineering, Isfahan University of Technology, Isfahan, Iran

Sayed Mohammad Hosseini, MSc, Department of Chemical Engineering, Islamic Azad University, Shahroud Branch, Shahroud, Iran

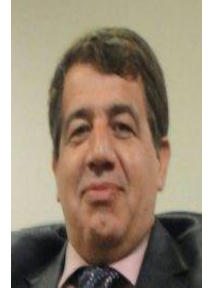

Professor Saeid Eslamian, is a full professor of water system engineering in the Department of Water Engineering at Isfahan University of Technology, Iran, where he has been since 1995. He received his PhD from Civil and Environmental Engineering School, University of New South Wales, Sydney, Australia, under the supervision of Professor David Pilgrim. His research focuses mainly on water resources planning, management, and sustainability and statistical and environmental hydrology in a changing climate. Formerly, he was a visiting professor at Princeton University, New Jersey, and University of ETH Zurich, Switzerland. On the research side, he started a research partnership in 2014 with McGill University, Montreal, Quebec, Canada. He has contributed to more than 600 publications in journals, books, or as technical reports. He is the founder and chief editor of both the International Journal of Hydrology Science and Technology (Scopus, Inderscience) and the Journal of Flood Engineering. Professor Eslamian is also associate editor of the Journal of Hydrology (Elsevier) and Ecohydrology and Hydrobiology (Elsevier). He has authored more than 150 book chapters and books. Recently, Professor Eslamian published eight handbooks with Taylor \& Francis Group (CRC Press) as chief editor: a three-volume Handbook of Engineering Hydrology (2014), Urban Water Reuse Handbook (2015), a three-volume Handbook of Drought and Water Scarcity (2017), and Underground Aqueducts Handbook (2016).

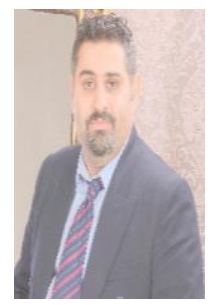

Dr. Kaveh Ostad-Ali-Askari, is a $\mathrm{PhD}$ of civil engineering, Department of Water Resources Engineering, Faculty of Civil Engineering. His topics of interest include Groundwater Hydrology, Irrigation and Drainage Engineering, Sustainable Development and Environmental Assessment, Climate and Integrated and Sustainable Water Resource Management, Water System Engineering, Water Resources Planning, Artificial Neural Network, and Genetic Algorithm. He has contributed to more than 124 publications in Journals, Books and Technical Reports. He collaborates as Editorial Board Membership in more than 16 Journals and as reviewers in more than 10 Journals. Currently, he is a Faculty Member of the Department of Civil Engineering, Isfahan(Khorasgan) Branch, Islamic Azad University, Iran.

Citation: Dr. Kaveh Ostad-Ali-Askari et al. (2017). Optimizing Absorbent Bentonite and Evaluation of Contaminants Removal from Petrochemical Industries Wastewater. International Journal of Constructive Research in Civil Engineering, 3(2), pp.34-42.

Copyright: $\odot 2017$ Dr. Kaveh Ostad-Ali-Askari, et al. This is an open-access article distributed under the terms of the Creative Commons Attribution License, which permits unrestricted use, distribution, and reproduction in any medium, provided the original author and source are credited 